\title{
MANAJEMEN KONFLIK BERBASIS "MULTICULTURAL COMPETENCES": SOLUSI ALTERNATIF KONTESTASI PRIBUMI DAN SALAFI DI LOMBOK
}

\author{
Mohamad Iwan Fitriani \\ Program Studi PAI Pascasarjana IAIN Mataram \\ Email: iwanfitriani@gmail.com
}

\section{Abstract}

The relationship between salafism and indigeneous moslem at Lombok caused several contestations and needed to be studied deeply. In this study, salafism and indigeneous moslem will be classified into rural and urban. This classification based on their unique relations: (1) salafism gets high resistence from rural indigenous moslems, (2) meanwhile, salafism receives tolerance from urban indigenous moslem. This study uses qualitative approach with interpretive paradigm to answer causes of rural indigeneous moslems resistences toward rural salafism, causes of urban indigeneous moslems tolerance toward urban salafism and how to formulate conflict management based on multicultural competences. This study shows that different responses of indigenous moslems toward salafism aren't only caused by the contestations of Ahlu-al sunnah but also many other elements. Then, multicultural competences needed to be developed by religious elite as an alternative to manage conflict in plural society for the sake of peace built on reciprocal multicultural values

Relasi antara antara salafi dan pribumi di Lombok telah melahirkan berbagai kontestasi yang perlu diulas secara mendalam. Dalam kajian ini, salafi dan pribumi diklasifikasi menjadi dua yaitu salafi desa dan kota serta pribumi desa dan kota. Klasifikasi ini didasarkan pada keunikan relasinya: (1) salafi desa mendapat resistensi tinggi dari muslim pribumi desa, (2) salafi kota mendapatkan 
toleransi dari pribumi kota. Kajian ini menggunakan pendekatan kualitatif dengan paradigma interpretatif untuk menjawab penyebab resistensi pribumi desa terhadap salafi desa, penyebab toleransi pribumi kota terhadap salafi kota serta bagaimana rumusan model manajemen konflik berbasis kompetensi multikultural. Kajian ini menunjukkan bahwa perbedaan respon pribumi terhadap salafi tidak hanya disebabkan oleh kontestasi ahlu al-sunnah tetapi juga banyak unsur-unsur yang lain. Selanjutnya, multicultural competence perlu dikembangkan oleh elit agama sebagai alternatif manajemen konflik dalam realitas sosial yang plural demi kerukunan yang dibangun oleh nilai-nilai resiprokal-multikultural.

Keywords: conflict management; salafism; indigenous; multicultural competences

\section{Pendahuluan}

Geliat kaum Salafi semakin mengemuka di Indonesia, tidak terkecuali di Lombok yang dikenal dengan bumi seribu masjid. Hal ini menambah pluralitas masyarakat Lombok yang memang sudah dikenal sebagai masyarakat plural, baik dalam hal suku, bahasa, adat istiadat termasuk agama. Khusus untuk agama, keragamaan bukan hanya bersifat eksternal tetapi juga internal. Keragaman internal disebabkan bukan hanya karena variasi organisasi dakwah dan keagamaan (NU, NW dan Muhammadiyah), tetapi juga varian Islam dengan tipikal religiusitas yang tidak sedikit memiliki perbedaan antara satu dengan yang lain.

Memang, penelitian dialektika salafi dan Islam pribumi/tradisional di Lombok bukanlah hal yang baru, diantaranya adalah penelitian Abdurrachman (2013 : 45-46). Penelitian ini difokuskan pada bentuk resistensi dan faktorfaktor resistensi salafi terhadap Islam tradisional. Hasil penelitiannya adalah resistensi aliran salafi terhadap Islam tradisional beranjak dari wacana implementasi Ijma' dan Qiyas sebagai dasar hukum tambahan dalam praksis keagamaan umat Islam tradisional di Lombok Barat. Menurut salafi, kedua dasar hukum Islam ini membuka peluang praktik tahayyul, bidah dan khurafat. Sedangkan faktor resistensi salafi terhadap Islam tradisional adalah tafsir tekstual dan kontekstual serta klaim ahlussunnah wal jamaah (Abdurrachman, 2013 : 45-46). Begitu juga penelitian Faizah (2012a) dan Tantowi (2009). Berbeda dengan kajian-kajian di atas, kajian ini ditekankan pada Islam pribumi atau Islam mainstream masyarakat Sasak dalam merespon keberadaan salafi dengan menelaah perbedaan respon di desa dan di kota. 
Berkaitan dengan penelitian ini, eksistensi salafi di Lombok diklasifikasi secara geografis menjadi salafi kota dan salafi desa. Salafi kota adalah salafi yang tinggal di kota Mataram seperti di Lawata Mataram (masjid dan sekolah Abu Hurairah), Masjid Jami' Cakranegara Mataram dan Masjid at-Taqwa Mataram. Sedangkan salafi desa adalah salafi yang mukim di dekat atau membaur dengan masyarakat di berbagai kabupaten dan desa di Lombok. Klasifikasi salafi kota dan salafi desa dalam hal ini didasarkan atas fakta bahwa walau memiliki paham keagamaan yang relatif sama antara salafi kota dan desa tetapi mereka memiliki keunikan yang menarik untuk diteliti.

Keunikan tersebut terlihat ketika membandingkan realitas antara salafi di kota dengan di desa. Eksistensi salafi kota "relatif" aman, nyaman dan jauh dari gangguan seperti serangan, ancaman, pengusiran dari kelompok mayoritas, andaikan pernah terjadi konflik, tetapi tidak sebesar konflik di desa. Sementara salafi desa justru sebaliknya tidak sedikit menerima; (1) tahkim/arbitrase lokal baik oleh tokoh agama setempat yang dalam bahasa Sasak disebut dengan "tesidang" (disidang), (2) mengalami isolasi atau pengusiran oleh warga setempat, (3) dihadapkan pada dilema antara diam menetap di tempat semula dengan syarat berhenti menjadi salafi atau tetap salafi tetapi harus meninggalkan kampung halamannya. Sebuah pilihan yang tidak ada jawabannya karena berkaitan bukan hanya keyakinan (vertikal) tetapi juga sederet sejarah sosial, seperti rumah, asal-usul keluarga dan kenangan masa kecil.

Fakta-fakta empirik yang menunjukkan perbedaan "nasib" antara salafi kota dan desa di antaranya adalah: (a) tahkim benih salafi di desa Golong Narmada, (b) pengusiran salafi di Batu Kliang Lombok Tengah tanggal 10 Juni tahun 2015 (Radar Lombok, 10 Juni 2015), (c) perusakan rumah salafi di Dasan Kembar Gerung Lombok Barat, (d) penghentian dakwah salafi di Gunungsari Lombok Barat, (e) perusakan masjid/musala milik salafi di Sekotong Lombok barat. Satu hal yang perlu dicatat adalah deretan fakta-fakta ini terjadi di luar kota Mataram (di desa) yang secara tegas mengindikasikan perbedaan respon terhadap salafi di kota dan di desa.

Oleh karena itu, tulisan ini difokuskan pada penyebab resistensi pribumi desa terhadap salafi desa di Lombok Nusa Tenggara Barat, penyebab toleransi Pribumi Kota terhadap salafi kota di Kota Mataram Lombok Nusa Tenggara Barat dan model manajemen konflik berdasarkan kompetensi multikultural serta implikasinya bagi elit agama di masyarakat Lombok pada umumnya.

Salah satu upaya yang dilakukan adalah dengan mengembangkan kompetensi multikultural (multicultural competences). Hal ini untuk menegaskan 
bahwa multikultur bukan hanya persoalan pendidikan formal di sekolah/ madrasah tetapi juga di tengah masyarakat beserta elemen-elemennya. Secara umum, multicultural competence ini merujuk pada kesadaran, pengetahuan dan sikap terhadap perbedaan. Dalam tulisan ini, digunakan teori dari Boutto (1999 dalam Lee, 2015) untuk melihat bagaimana manajemen konflik berbasis multikultural kompetensi (multicultural competence) ini dibangun berdasarkan relasi pribumi dan salafi di Lombok. Adapun rincian dari teori Boutto tersebut digambarkan dalam tabel di bawah ini:

Tabel I: Tiga Tahap Kompetensi Multikultural

\begin{tabular}{llll}
\hline & \multicolumn{1}{c}{ Level I } & \multicolumn{1}{c}{ Level II } & \multicolumn{1}{c}{ Level III } \\
\hline $\begin{array}{l}\text { Level of } \\
\text { Awareness }\end{array}$ & $\begin{array}{l}\text { My perspective is right } \\
\text { and only one }\end{array}$ & $\begin{array}{l}\text { My perspective is one } \\
\text { of many }\end{array}$ & $\begin{array}{l}\text { My perspective is } \\
\text { changing and being } \\
\text { enhanced }\end{array}$ \\
\hline $\begin{array}{l}\text { Emotional } \\
\text { Response to }\end{array}$ & $\begin{array}{l}\text { Fear, rejection, denial, } \\
\text { we're all alike }\end{array}$ & $\begin{array}{l}\text { Interest, awareness, } \\
\text { openness }\end{array}$ & $\begin{array}{l}\text { Appreciation, respect, } \\
\text { joy, enthusiasm/ } \\
\text { active seeking }\end{array}$ \\
\hline $\begin{array}{l}\text { Mode of } \\
\text { Curriculum }\end{array}$ & $\begin{array}{l}\text { Isolation, avoidance, } \\
\text { hostility }\end{array}$ & $\begin{array}{l}\text { Integratio, } \\
\text { interaction, } \\
\text { acceptance }\end{array}$ & $\begin{array}{l}\text { Transforming, } \\
\text { internalizing, } \\
\text { rewarding }\end{array}$ \\
$\begin{array}{llll}\text { Approach to } \\
\text { Teaching }\end{array}$ & $\begin{array}{l}\text { Ethnocentric } \\
\text { curriculum }\end{array}$ & $\begin{array}{l}\text { Learning about other } \\
\text { culture }\end{array}$ & $\begin{array}{l}\text { Learning from other } \\
\text { culture }\end{array}$ \\
\hline $\begin{array}{l}\text { Approach to } \\
\text { Management }\end{array}$ & $\begin{array}{l}\text { Monocultural } \\
\text { authocratic, directive }\end{array}$ & $\begin{array}{l}\text { Compliance, } \\
\text { tolerance }\end{array}$ & $\begin{array}{l}\text { Collaborative, } \\
\text { valuing diversity, } \\
\text { maximizing potential }\end{array}$ \\
\hline
\end{tabular}

Sumber: adaptasi dari Stage of Multicultural Growth (Boutto, 1999 dalam Lee, 2015)

Berdasarkan tabel di atas, manajemen konflik diarahkan pada bagaimana upaya mentransformasi sikap keberagamaan dari tahap 1, ke tahap 2 dan selanjutnya ke tahap 3. Misalnya dari segi kesadaran diri (self awareness), diperlukan transformasi sudut pandang dari hanya pendapatku yang benar (my perspective is right, only one) menuju pendapatku, aliranku, keyakinanku adalah salah satu dari berbagai pendapat, aliran atau keyakinan yang banyak ( $m y$ perspective is one of many) lalu ke pendapatku berubah dan sedang ditingkatkan (my perspective is changing and being enchanced) dan seterusnya.

Kemudian, barometer multikulturalisme menurut Karuna Center for Peacebuilding sebagaimana dikutip Misrawi (2013: 203-204) yaitu: pertama, hidup berdampingan secara damai dan kesamaan hak di antara warga negara 
(co-existence). Kedua, adanya keterbukaan untuk melihat kelompok lain sebagai warga negara dan makhluk Tuhan yang mempunyai kesempatan sama di depan hukum (awareness). Ketiga, pengenalan terhadap kelompok lain sembari melakukan dialog konstruktif (mutual learning). Keempat, pemahaman atas kelompok lain (understanding). Kelima, penghormatan dan pengakuan terhadap kelompok lain (respect). Keenam, penghargaan pada persamaan dan perbedaan, serta merayakan kemajemukan (value and celebration). Tingkatan yang terakhir ini menjadi barometer yang paling baik dalam rangka mengukur sejauh mana multikulturalisme benar-benar terwujud dalam sebuah masyarakat. Merayakan keragaman merupakan salah satu puncak dari multikulturalisme, karena perbedaan dapat dipahami sebagai salah satu keniscayaan, bahkan kekuatan untuk membangun kebersamaan (Misrawi, 2013: 204).

Sikap-sikap tersebut bisa terwujud apabila didasari sikap "saling" atau apa yang disebut Edward (2015: 27-28) dengan resiprokasi nilai (reciprocation of values). Hal inipun ditegaskan dalam ajaran Islam bahwa, "Sayangilah orang-orang yang di bumi, maka Anda akan disayang yang di langit" (irhamu man fil ardhi, yarhamkum man fis sama'). Dalam istilah Nieto (1994), terdapat nilai-nilai yang pendukung (supporting values) multikultural ini yaitu tolerance, acceptance, respect, affimation and solidarity, critique sehingga terwujud sikap-sikap yang dalam teori Otherness Development Model (ODM) dikenal dengan 3Rs and 2Ss (relathionship, respectablity, responsiblity, sensitivity anf sensiblity).

Gambaran dari tujuan ODM di atas adalah sikap bagaimana orang bisa menjadi bagian dari orang lain dan sebaliknya (relationship), bisa dihormati dengan menghormati orang lain (respectability), memiliki tanggung jawab dalam wujud kemampuannya untuk menempatkan diri secara tepat di tengah perbedaan (responsibility), serta memiliki sensitivitas yaitu pemikiran imaginatif tentang hasil dari sebuah tindakan (imaginative thoughts about the possible outcomes of actions or inactions) dan sensibilitas sosial yang berkaitan dengan kemampuan untuk mendemonstrasikan kebajikan, pengetahuan dalam upaya untuk memahami orang lain. Yang terakhir adalah sensibilitas, di mana sensibilitas seseorang ditunjukkan dalam penilaiannya berdasarkan etika dan situasi moral sosial (Lovett \& Jordan, 2010 dalam Edward, 2015: 26-28).

\section{Metode Penelitian}

Penelitian ini mengggunakan rancangan kualitatif deskriptif jenis fenomenologis. Peneliti adalah instrumen kunci sementara informan ditentukan secara purposive sampling serta mengalir seperti bola salju (snow ball sampling).

el Harakah Jurnal Budaya Islam Vol.18 No.1 Tahun 2016 
Data dijaring melalui wawancara mendalam yaitu wawancara kepada tokohtokoh Islam pribumi baik dari kalangan masyarakat Pribumi Lombok ataupun para ahli di perguruan Tinggi, khususnya IAIN Mataram serta pihak-pihak yang dianggap dapat memberikan informasi yang mendalam tentang penelitian ini. Dalam wawancara ini, informan tidak ditentukan berdasarkan kuantitasnya tetapi pada kualitas atau kedalaman informasi yang diberikan untuk menjawab pertanyaan penelitian. Selanjutnya adalah observasi serta dokumentasi yang terkait dengan penelitian. Untuk mempertajam penyaringan data, digunakan juga Focus Group Discussion (FGD). Setelah data terjaring, data dianalisis melalui alur data colletion, data reduction, data display dan conclusion. Demi trustworthiness penelitian ini, digunakan langkah-langkah yaitu menentukan kredibilitas, dependabilitas, konfirmabilitas dan transferabilitas.

\section{Gambaran Umum Islam Pribumi Dan Salafi Lombok}

Pulau Lombok merupakan salah satu pulau dalam wilayah Provinsi Nusa Tenggara Barat. Lombok sendiri terdiri dari 1 Kotamadya dan 4 Kabupaten yaitu Kotamadya Mataram, Kabupaten Lombok Barat, Lombok Tengah, Lombok Timur dan Lombok Utara. Pulau Lombok dikenal juga dengan Gumi Sasak atau Gumi Seribu Masjid. Gumi Sasak dikenal akan pluralitasnya baik internal maupun eksternal. Di antara pluralitas internal tersebut adalah pluralitas internal dalam agama Islam yang dikenal dengan varian salafi dan pribumi. Dialektika keduanya telah melahirkan aneka bentuk konstruksi sosial baik yang bersifat asosiatif dan dissosiatif.

Istilah pribumi dalam Islam sering diidentikkan dengan upaya untuk membumikan Islam (indigenisasi). tidak mengherankan bila Gus Dur ingin mengafirmasi realitas demi universalisasi ajaran Islam dengan istilah Islam Pribumi. Gus Dur adalah tokoh yang memperkenalkan istilah Islam Pribumi. Istilah Islam pribumi ini sering dikonfrontasikan dengan Islam authentic, Islam puritan atau Islam Salafi. Islam Salafi memiliki kaitan erat dengan Wahabi, sebuah gerakan yang dinisbahkan kepada Muhammad bin Abdul Wahhab, walau sebenarnya mereka menyebut diri dengan al-Muwahhidun. Salafi juga dikaitkan dengan Madzhab Imam Ahmad bin Hambal (Hamid \& Yaya, 2010: 101). Selain wacana kembali kepada al-Qur'an dan as-Sunnah, salafi juga mengajak untuk mengikuti tradisi ulama salaf serta perilaku sahabat, tabi'in dan tabi'uttabi'in.

Dalam kajian ini, salafi dan pribumi dibagi menjadi salafi kota dan salafi desa. Salafi kota adalah mereka yang tinggal di ibu kota provinsi Nusa Tenggara 
barat yaitu kota Mataram. Sedangkan salafi desa adalah mereka yang tinggal di berbagai desa/dusun di seluruh kabupaten Lombok (khususnya Lombok Barat) Nusa Tenggara Barat. Selanjutnya, ketika berbicara salafi di kalangan Islam Sasak Lombok, memori kolektif masyarakat Sasak biasanya tertuju pada sederet ciri antara lain; 1) berjenggot, 2) berjubah putih, 3) celana yang dilipat di atas mata kaki, 3) parfum khas Arab, 4) yang paling khas adalah pemahamannya yang "rigid", kaku, tekstual dengan menjadikan era sahabat, tabi'in dan tabi'uttabi'in sebagai rujukan utama ucapannya. Poin terakhir inilah yang sering ditemani oleh pengalamatan statement, syirik, bidah, dhalal kepada yang tidak sepaham keagamaan dengan mereka. Model pemahaman kaum salafi yang kaku dan tekstual tersebut berujung pada sikap eksklusif dan berhadapan langsung dengan keberagamaan masyarakat Sasak yang secara umum dibangun oleh dua mainstream yaitu: (1) mainstream Islam lokal Sasak yang sarat dengan penyisipan tradisi dalam aktualisasi keberislaman. Karena Lombok merupakan tempat bertemunya tiga kebudayan besar Nusantara yaitu kebudayaan Jawa Kuno (Hindu Majapahit), Islam, dan Hindu (Hindu Bali) (Faizah, 2012b: 67)

Karena itu, tidak heran bila keberislaman masyarakat Sasak sangat kental dengan tradisi yang dipengaruhi oleh ketiga budaya tersebut, yaitu Hindu (Bali), Majapahit (Jawa), bahkan Sumatra serta kolonial Belanda dan Jepang. Hal tersebut ditambah lagi dengan kehadiran para tuan guru yang mayoritas menyampaikan Islam moderat di bumi Lombok. Berdasarkan hasil penelitian Yusuf Tantowi, di kota Mataram terdapat dua pusat penyebaran Salafi. Pertama, Islamic Centre Abu Hurairah, Lawata, Gomong Lama. Pimpinannya bernama Ust. Ibnu Hizam, salah seorang distributor dana-dana pembangunan Wahabi. Bangunan berlantai dua ini meniru gaya arsitektur Timur Tengah. Lantai satu dipergunakan salat dan kajian, sedangkan lantai dua dijadikan tempat belajar yang disebut Lembaga Pendidikan Islam Terpadu Abu Hurairah. Biaya belajar di tempat ini digratiskan. Kedua, masjid Islamic Centre, Cakranegara. Masjid ini sering dijadikan sebagai tempat pengajian pengikut salafi dari berbagai daerah di NTB. Di tempat ini juga sering didatangi oleh dai-dai salafi dari Jawa bahkan dari Arab Saudi (Tantowi, 2009: 41). Seiring berjalannya waktu, saat ini pusat salafi juga berada di masjid at-Taqwa Mataram. Sehingga di kota Mataram, pusat salafi ada tiga. Dari ketiga pusat ini selanjutnya salafi bisa menyebar ke berbagai kampung/dusun di Lombok Nusa Tenggara Barat.

Namun, walau salafi memiliki tiga pusat di kota Mataram, genealogi salafi adalah di Lombok Timur. Tantowi menyebutkan bahwa penyebaran salafi di 
Pulau Lombok dimulai dari kabupaten Lombok Timur sekitar tahun 1990. Ajaran salafi dibawa oleh almarhum TGH. Husni Abdul Manan, putra seorang tuan guru NU kelahiran Bagek Nyaka, desa Kembang Kerang, kecamatan Aikmel. Besarnya pengaruh almarhum ayahnya menyebabkan TGH. Husni dalam waktu yang tidak relatif lama mendapatkan pengikut cukup banyak. Tak heran tahun 1995, pengikutnya hampir tersebar di semua desa di Lombok Timur (Tantowi, 2009: 27). Selain di Lombok Timur, salafi juga hadir di berbagai belahan bumi Sasak baik di kabupaten Lombok Tengah, Lombok Barat dan Lombok Utara serta satu kota Mataram.

\section{Penyebab Resistensi Pribumi Desa terhadap Salafi Desa di Lombok}

Dialektika antara salafi desa dan pribumi desa menegaskan apa yang dinyatakan oleh Ferdinand Tonnies (1855-1936) yang membagi masyarakat ke dalam dua jenis kelompok, yaitu gemeinschaft dan gesellschaft. Sebagai masyarakat gemeinschaft (paguyuban) masyarakat desa kental dengan sikap eksklusif baik karena alasan darah, tempat atau pikiran yang dalam hal ini adalah pemikiran keagamaan (gemeinscharft by blood, gemeinschaft of place, dan gemeinschaft of mind). Resistensi itu menyiratkan interaksi yang bersifat dissasosiatif seperti persaingan (competition) antara tokoh atau umat yang berbeda pandangan keagamaan serta konflik baik vertikal maupun horizontal. Hal ini disebabkan oleh salafi yang menginginkan purifikasi ajaran Islam di satu sisi sementara di sisi lain Islam pribumi ingin menyelamatkan Islam dari ajaran salafi. Secara lebih spesifik, ada beberapa hal yang menyebabkan resistensi pribumi desa terhadap salafi desa di Lombok Nusa Tenggara Barat yaitu:

\section{Pertama, kontestasi pengaruh antar tokoh}

Kontestasti pengaruh antar elit agama juga memberi kontribusi bagi resistensi pribumi terhadap salafi. Menurut Muhlis (wawancara 23 Agustus, 2015), dan I. R. Suhandra (20 Desember 2015) hal ini terjadi karena elit agama (kiai, tuan guru, ustadz, tokoh masyarakat setempat) telah memiliki pengaruh yang lama dan mendalam di tengah masyarakat desa. Apabila ada sesuatu yang baru datang, lebih-lebih yang baru itu berbeda dengan apa yang diajarkan oleh elit agama tersebut, otomatis akan terjadi perebutan pengaruh. Sehingga tidak heran bila resistensi terhadap salafi juga dimotori elit-elit agama di desa.

Islam Sasak (sebutan bagi warga asli Lombok) adalah Islam yang disamping ditopang kuat oleh dialektika Islam universal dengan lokal juga ditopang oleh tradisi keberagamaan yang kuat (fanatisme keberagamaan yang tinggi) karena 
didasari oleh kebenaran otoritatif yang diperoleh dari tuan guru. Secara bahasa kata tuan guru berasal dari kata "tuan" yang berarti haji dan 'guru" berarti guru. Namun, tidak semua haji disebut tuan guru. Menjadi tuan guru dalam perspektif masyarakat Sasak harus memiliki keilmuan yang tinggi (khususnya di bidang agama) yang selanjutnya dengan keilmuan itu mendapat legitimasi sosial di tengah masyarakat, baik karena penyampaian keilmuan tersebut di pesantren, pengajian umum, majlis taklim atau dengan turun langsung atas berbagai undangan hajatan di tengah masyarakat (dzikir, tahlilan, roah, serakalan dan lain-lain).

Mainstream Islam yang didakwahkan oleh para tuan guru di Lombok biasanya berasal dari organisasi keagamaan mayoritas di Pulau Lombok yaitu Nahdlatul Wathan (NW) dan Nahdlatul Ulama (NU). Para tuan guru baik dari kalangan NW maupun NU (secara mayoritas bahkan semuanya) mengusung teologi al-Asy'ari, fikih as-Syafi'i dan tasawuf al-Ghazali yang berciri khas moderat. Hasil penelitian Faizah (2012b:67), misalnya, menunjukkan bahwa dalam masalah teologi, mayoritas masyarakat Sasak mengikuti pandangan aliran al-Asy'ari yang dinisbatkan pada pendirinya Abu Hasan al-Asy'ari yang memahami bahwa sifat-sifat khabariyah yang terdapat dalam beberapa ayat alQur'an bersifat metaforis yang memerlukan takwil (interpretasi).

\section{Kedua, anggapan bahwa salafi keluar dari mainstream Islam Sasak}

Bagi masyarakat Sasak, khususnya di desa, mainstream pemikiran tidak hanya memiliki makna mayoritas, tetapi juga kebenaran (majority means truth). Tidak sedikit yang melegitimasi pendapatnya dengan kaidah, "Imtina" tawathu'uhum 'alal-kadzibi fil-adah." (tidak mungkin secara ketepatan berbohong bersama). Sehingga, ketika muncul wacana keagamaan dari minoritas, maka minoritas dianggap keluar dari mainstream pemikiran yang juga berarti suatu kesalahan yang memerlukan pelurusan.

Mainstream keberagamaan masyarakat Sasak adalah Islam yang berteologikan Imam Hasan al-Asy'ari dan Imam Abu Manshur al-Maturidzi, berfikihkan Imam as-Syafi'i dan bertasawwufkan Imam al-Ghazali. Hal ini dibawa oleh para tuan guru alumni Timur Tengah di Lombok yang selanjutnya diperkuat oleh keberadaan organisasi yang ada seperti NW yang didirikan oleh TGKHM. Zainuddin Abdul Madjid dan NU yang didirikan oleh K. H. Hasyim Asy'ari. Mayoritas mayarakat Lombok mengikuti teologi Asy'ariMaturidi, fikih as-Syafi'i dan tasawuf al-Ghazali. Salafisasi yang keras dan mengganggu kenyamanan keberagamaan masyarakat Sasak (klaim syirik, bidah dan takhayul) merupakan benih kontestasi yang lazim terjadi di Lombok.

el Harakah Jurnal Budaya Islam Vol.18 No.1 Tahun 2016 
Keberadaan kiai dan tuan guru dalam masyarakat Desa Sasak Lombok bukan sebatas tokoh teladan dalam perilaku, tetapi juga dalam hal aliran kegamaan. tuan guru dianggap sebagai representasi ajaran Tuhan. Kemampuan agama yang dimiliki, yang didukukung oleh kemampuan bahasa untuk memahami sumber primer dan sekunder ajaran Islam membuat masyarakat menjadikannya sebagai sosok sumber kebenaran keberagamaan masyarakat Sasak. Kemampuan yang dimiliki oleh tuan guru direspon dengan penerimaan (acceptabilitas) yang tinggi berupa fanatisme, bahkan tidak sedikit yang menyakralkan seseorang. Model kebenaran otoritatif inilah yang apabila ditentang atau diserang oleh ajaran lain membuat masyarakat Sasak pribumi pasang badan untuk membelanya.

Adalah hal yang lumrah jika kedua organisasi tersebut memiliki mayoritas pendukung di Gumi Sasak Lombok. Mereka memiliki amalan-amalan yang di samping merupakan hasil ijtihad dari para ulama madzhab juga dipengaruhi oleh budaya lokal. Diantaranya adalah serakalan, maulidan, barzanji, ziarah kubur, tahlilan/roah ataupun tradisi berbau lokal yang disisipkan ajaran Islam seperti nelung (ritual 3 hari pasca kematian seseorang), mitu' (ritual 7 hari pasca kematian seseorang), nyiwa' (ritual 9 hari pasca kematian seseorang), nyatus dan nyiwu (ritual seratus dan seiru hari hari pasca kematian), pelampak (sedekah untuk yang telah meninggal) dan sebagainya. Semua ritual-ritual keberagamaan muslim pribumi desa tersebut telah lama dan mengendap menjadi tradisi turun-temurun. Tak pelak, ketika itu disanggah dan diklaim sebagai aberrative ritual oleh salafi, maka sikap awal yang moderat para pengikut Imam Abu Hasan al-Asy'ari dan Imam Abu Manshur al-Maturidzi itupun berubah menjadi garang di desa.

Sejatinya Islam Sasak Lombok adalah Islam toleran atau Islam moderat. Dalam hal ini menarik yang dikatakan oleh Ridwan (wawancara, 20 September, 2015) yaitu Islam Sasak Lombok cukup toleran, walau sering terjadi konflik dengan salafi, itu terjadi karena Salafi yang agresif menyerang Islam moderat. Salafi seringkali menyalahkan keberagamaan Islam Sasak yang kuat dengan tradisi hiziban (kegiatan membaca doa kumpulan dari Syekh TGKH M. Zainuddin Abdul Madjid, Pendiri organisasi Nahdlatul Wathan di Pancor Lombok NTB), barzanji, serakalan, roah/tahlilan (Dzikir spritual, ruh/roah untuk mengingat keluarga yang sudah meninggal dengan aneka bacaan-bacaan Islami dari al-Qur'an dan Hadis serta doa yang dikarang oleh para ulama), talqin, maulid dan yang lain. Sementara mereka (Islam Sasak) tidak ingin Islam yang diterima dari para tuan guru disalahkan bahkan dianggap bidah, syirik 
dan sebagainya. Andai salafi tidak seperti itu, mereka tidak akan diusir, tidak akan dibakar rumahnya taupun lainnya, mereka agresif dan tidak adaptif.

Selanjutnya, sebuah analogi menarik dari Kurnain (wawancara 6-7 Agustus 2015) tentang salafi Lombok vs Islam moderat yaitu salafi Lombok menganggap diri lurus terus lawan arus. Andaikan Islam itu adalah sungai besar yang diisi oleh dua perahu yaitu besar dan kecil, perahu besar (Islam moderat Sasak) berjalan ke barat, sementara perahu kecil (Islam salafi) melawan arus ke timur. Setelah lawan arus, perahu kecil itupun menyalahkan perahu besar yang ke barat dan mengajaknya ke timur, yang lebih parah lagi adalah nahkoda perahu itupun (tuan guru) dianggap keliru dalam menakhkodai perahu besar. Seisi perahu besar itupun lalu mendorong, merusak bahkan berupaya membakar perahu kecil.

\section{Ketiga, anggapan bahwa salafi dianggap tidak kompak}

Bagi masyarakat Sasak muslim desa di Lombok, salah satu ciri keberislaman mereka adalah kebersamaan dalam ritualitas. Tidak mau bersama dianggap berbeda, jika yang menolak itu adalah Muhammadiyah, dalam beberapa hal ditolerir, karena itu jarang terjadi konflik NU-NW dan Muhammadiyah secara sosial dan horizontal. Tetapi jika salafi, maka langsung akan ditahkim secara lokal. Karena salafi menolak bukan sebatas dengan sikap tetapi juga opini yang dialamatkan ke mayoritas yang mengajaknya. Hal ini menunjukkan bahwa walaupun Muhammadiyah di Lombok (seperti di desa Golong Narmada) berbeda dengan Islam pribumi, mereka mendapat toleransi karena perbedaan tersebut tidak diwujudkan secara vulgar seperti salafisasi di atas.

Kebersamaan dalam ritualitas mengindikasikan apa yang dalam sosiologi disebut dengan minna wa minhum (our and out group). Misalnya, jika jama'ah memiliki keyakinan bahwa tahlilan, barzanji, hiziban dan syerakalan adalah bagian dari upaya mendekatkan diri (taqarrub) kepada Allah, maka mereka akan membentuk kelompok tahlilan, barzanji, hiziban dan syerakalan. Syerakalan adalah istilah yang berasal dari asyraqa dalam asyraqa al-badru 'alaina. Tradisi Sasak ini berisi puji-pujian kepada Nabi Muhammad saw. yang disertai dzikir atau roah.

Bagi masyarakat Sasak, salafi adalah sebuah kelompok atau aliran keagamaan yang memiliki pengamalan keagamaan yang berbeda dengan mereka. Masuknya paham salafi secara kontinyu melalui pengajian, mengecam praktek-praktek agama dan kultural yang secara nyata dilakukan oleh masyarakat Sasak merefleksikan usaha kelompok salafi untuk melakukan purifikasi. Hal 
ini karena mereka menganggap pengamalan keagamaan masyarakat Sasak banyak diwarnai bidah. Di sisi lain, kelompok Salafi berhadapan dengan budaya masyarakat Sasak yang mengutamakan komunitas dan solidaritas sosial. Sedangkan masyarakat Sasak menganggap bahwa sebuah kultur lokal dapat diterima sejauh tidak bercampur dengan ibadah Islam dan bertentangan dengan ajaran-ajaran Islam yang mendasar (Faizah, 2012: 377).

\section{Keempat, terbiasa dengan homogenitas}

Pola keberagamaan muslim pribumi Sasak juga ditandai oleh kebiasaan akan homogenitas. Bersatu dan tinggal bersama berdasarkan agama serta tuan guru yang sama adalah salah satu karakteristik mayoritas Islam Sasak. Homogenitas tersebut menjadi kekuatan untuk menjaga kemapanan (establishment) dalam paham keberagamaan (wawancara dengan I. Rama Suhandra, 20 Desember 2015). Misalnya, di Narmada terdapat daerah berbasis NU, berbasis NW, berbasis Muhammadiyah dan berbasis Salafi.

Sesuatu yang menarik menurut Riyanto (wawancara Oktober 2015) adalah Islam pribumi lebih memperhatikan salafi daripada non-muslim. Misalnya di Suranadi (sebuah desa di kecamatan Narmada Lombok Barat) yang merupakan desa di mana Islam dan Hindu berbaur dan di desa Peninjauan (sebuah dusun di kecamatan Narmada Lombok Barat) di mana Hindu berbatasan dengan muslim desa Golong. Di dua tempat itu, dapat diamati (observasi AgustusDesember 2015), relasi Islam dan non-muslim berjalan harmonis, karena muslim menganggap berbeda agama itu suatu yang wajar. Tetapi jika dalam satu agama (Islam) terdapat pemahaman yang berbeda bahkan menyimpang dari kebiasaan mayoritas, maka itulah yang tidak wajar dan sering berujung konflik. Hal ini menunjukkan bahwa dalam beberapa hal, perbedaan eksternal agama "lebih dimaklumi" daripada perbedaan internal.

\section{Kelima, tingkat pendidikan masyarakat desa (kedewasaan intelektual)}

Masyarakat desa secara umum tidak sama pendidikannya dengan masyarakat kota. Memang, mayoritas kaum terdidik kota berasal dari desa, tetapi mereka yang tinggal di kota memiliki sikap yang adaptif (bukan munafik). Di kota bersikap plural, toleran sedang di desa ikut larut dalam fanatisme mayoritas. $\mathrm{Hal}$ ini membuat kedewasaan intelektual masyarakat menjadi rendah. Hal ini pula yang membuat banyak (tetapi tidak semua) sarjana, magister, bahkan doktor yang telah lama belajar atau mengajar di kota dengan pemikiran modern yang inklusif tetapi kembali menjadi eksklusif ketika mereka kembali ke desa. 
Mereka bisa jadi mengkritik kiai dan tuan guru di meja mengajar atau bangku kuliah, tetapi cium tangan dan sami'na wa ath'na ketika kembali ke desanya.

\section{Penyebab Toleransi Pribumi Kota terhadap Salafi Kota di Mataram Lombok NTB.}

Interaksi antara salafi kota dengan pribumi di kota lebih bersifat assosiatif yang ditandai dengan toleransi. Salah satu contohnya adalah banyak Islam pribumi yang turut salat berjamaah ketika mereka berada di masjid Cakra Negara yang merupakan salah satu pusat salafi (observasi Agustus-Desember 2015). Menurut Muhlis, Quddus, Razy (wawancara 5 Desember 2015), di antara hal yang menyebabkan terciptanya toleransi tersebut adalah:

\section{Pertama, muslim kota lebih plural serta lebih dewasa secara intelektual}

Menurut Quddus dan Razy (wawancara 5 Desember 2015), realitas komunitas masyarakat kota adalah plural dan heterogen. Pluralitas ini membuat mereka terbiasa dengan perbedaan yang bukan hanya dalam hal agama, budaya, bahasa ataupun tradisi, tetapi juga dalam aliran kepercayaan. Misalnya, di Lombok Barat dan di kota Mataram NTB, ditemukan sejumlah agama yang ada di Indonesia, yaitu agama Islam (mayoritas), baru disusul Hindu, Budha, Kristen dan Konghucu. Berbeda dengan Lombok Timur yang hampir semuanya beragama Islam. Realitas akan pluralitas di atas membuat pola keberagamaan masyarakat kota bersifat inklusif. Diantaranya adalah inklusif secara internal maupun eksternal.

Selanjutnya, kedewasaan intelektual itu disebabkan oleh tingkat pendidikan masyarakat kota lebih tinggi secara umum dibanding masyarakat desa (A. Quddus, wawancara 5 Desember 2015). Tingkat pendidikan masyarakat kota seperti di kota Mataram dapat ditemukan mulai dari jenjang S1 sampai S3. Walaupun sebenarnya mereka berasal dari desa tetapi tempat tinggalnya di kota yang membuatnya adaptif dalam menunjukkan keberagamaannya.

\section{Kedua, sifat individualis muslim kota}

Individualisme selama ini dianggap salah satu ciri negatif, namun mengingat bahwa tidak ada sesuatu yang diciptakan sia-sia maka individualisme masyarakat kota dalam beberapa hal memiliki sisi positif yaitu tidak mengganggu masyarakat lain. Selain itu, ciri-ciri negatif masyarakat kota yang individualis ternyata memberikan sumbangan bagi toleransi beragama. 


\section{Keempat, referensi ajaran agama yang variatif dan multi-perspektif}

Di kota, kiai dan tuan guru memang tetap menjadi rujukan, tetapi muslim pribumi kota juga memiliki referensi ajaran yang variatif seperti buku bacaan, internet dan lainnya. Dengan kata lain, fenomena peran kiai atau tuan guru lebih dominan di desa dari pada di kota. Karena di kota walaupun tuan guru tetap memiliki peranan penting, tetapi karena bukan yang dominan menjadi rujukan.

Keberadaan referensi ajaran yang variatif, multi-perspektif bahkan disertai wacana komparatif turut menentukan pandangan, sikap terhadap perbedaan. Karena itu, tidak mengherankan bila konflik pribumi dan salafi lebih banyak ditemukan di desa daripada di kota.

\section{Manajemen Konflik Berbasis Multicultural Competence dan Implikasinya bagi Elit Agama}

Relasi yang berujung kontestasi dan konflik antara pribumi dan salafi adalah hal yang lazim terjadi dalam masyarakat plural. Mendamaikan keduanya tidak bisa dengan berusaha menyatukan pemahaman mereka, karena hal ini sudah melibatkan keyakinan tentang jalan kebenaran yang terbaik menurut golongan masing-masing. Solusi terbaik adalah dengan memberikan pandangan akan nilai-nilai yang mendukung (supporting values) dalam merespon perbedaan yang dikenal dengan multicultural competence yang terdiri dari kesadaran akan perbedaan (awareness), pengetahuan tentang perbedaan (knowledge), kemampuan atau keterampilan (skill) serta sikap (attitude) dalam berinteraksi dan reaksi terhadap perbedaan.

Mengingat bahwa pribumi dan salafi yang dikaji dalam tulisan ini berada di tengah masyarakat dan bukan di lembaga pendidikan formal, maka sosok yang berperan dalam manajemen konflik kontestasi pribumi dan salafi itu adalah para elit agama. Elit agama yang dimaksud di sini adalah tokoh-tokoh agama yang terdiri dari kiai, ustadz, tuan guru ataupun TGKH (Tuan Guru Kiai Haji). Peran ini sangat penting karena dalam konteks masyarakat Lombok pada khususnya, elit agama adalah sosok identifikasi diri yang bukan hanya dalam berfikir tetapi juga berperilaku. Konsekuensinya, kebenaran perspektif elit adalah kebenaran yang juga banyak diikuti oleh masyarakat, baik di desa maupun di kota.

Merujuk pada (sebagian) pemikiran Mintzberg (dalam Edward, 2015), peran yang perlu dimainkan oleh elit agama adalah monitor role, disseminator, figure head, spokesman dan disturbance handler. Peran di atas saling berkaitan 
sehingga saling memasuki batas-batas yang satu dengan yang lain (penetrating boundaries). Adapun penjelasannya adalah:

Pertama, peran monitor role, dalam hal ini elit agama harus mampu memonitor atau mengawasi setiap tindak tanduk pengikutnya baik secara langsung maupun tidak langsung. Monitoring role dalam konteks salafi dan pribumi di Bumi Sasak terlihat dalam langkah preventif dan antisipatif yang dilakukan oleh elit agama yang berbeda aliran kepercayaan. Khususnya antara kiai, tuan guru dan tokoh salafi. Hal ini sulit terjadi ketika pimpinan tokoh agama memiliki pemahaman yang ekslusif. Alih-alih memonitor, yang terjadi adalah mendukung jama'ah sendiri sehingga konflik horizontal pun sering tidak terelakkan.

Kedua, peran diseminator, dalam hal ini elit agama diharapkan mampu mendiseminasikan nilai-nilai universal agama yang menganjurkan kedamaian, kerukunan dengan prinsip saling menghargai antar sesama termasuk terhadap aliran keagamaan yang berbeda. Para tokoh agama diharapkan menyampaikan nilai-nilai universal ajaran Islam demi mewujudkan al-islam rahmatan lil'alamin.

Ketiga, peran sebagai spokesman, dalam hal ini elit agama yang sering menjadi penceramah dalam pengajian diharapkan mampu menonjolkan toleransi dengan mengedepankan aspek usuliyyah agama daripada aspek furu'iyyah. Salah satu rutinitas pimpinan tokoh agama seperti tuan guru di Lombok adalah memberikan ceramah agama atau pengajian. Dalam pengajian, jarang disampaikan wacana komparatif, karena dianggap talfiq (mencampuradukkan madzhab). Sehingga, jika masyarakat pada umumnya sudah mendengarkan ajaran Imam as-Syafi'i (misalnya), maka hanya as-Syafi'i lah yang benar, begitu pula dengan lainnya. Namun, ada juga kiai atau tuan guru (walaupun jumlahnya sedikit) yang sudah mulai mewacanakan toleransi dengan sudut pandang baik teologis maupun sosiologis.

Keempat, peran disturbance handler, dalam hal ini elit agama sebagai korektor ataupun konselor ketika terjadi masalah dalam hubungan antara pribumi dan Salafi, para pemimpin diharapkan berada di garda depan untuk memberikan keputusan yang win-win solution. Peran ini juga berkaitan dengan peran negotiator yaitu para elit agama melakukan negosiasi dengan pihak lain baik dalam langkah preventif - antisipatif ataupun kuratif. Peran-peran di atas akan dikaitkan dengan supporting values dalam mewujudkan multicultural competence (awareness, knowledge, skill and attitude) sehingga, bila dikaitkan dengan teori multicultural competence di atas, maka tugas elit agama dalam manajemen konflik adalah:

el Harakah Jurnal Budaya Islam Vol.18 No.1 Tahun 2016 
Pertama, dari segi level kesadaran (level of awareness), elit agama bertugas untuk mentransformasi kesadaran seseorang terhadap perbedaan dari perspektif saya adalah yang benar dan hanya satu (my perspective is right and only one) menuju perspektif saya adalah salah satu dari berbagai perspektif yang lain (my perspective is one of many) bahkan meningkat menjadi sudut pandang saya berubah dan ditingkatkan (my perspective is changing and being enhanced)

Kedua, dari segi respon emosional terhadap perbedaan (emotional response to difference), elit agama bertugas untuk mentransformasi respon emosional terhadap perbedaan dari perasaan takut, menolak dan menyangkal terhadap perbedaan (fear, reject, denial) menuju respon yang membuat orang memiliki ketertarikan, kesadaran dan keterbukaan terhadap perbedaan (interest, awareness and openness) dan sikap menghargai (appreciation), menghormati (respect), senang dan antusias (joy and enthusiasm) dan aktif mencari (active seeking) hal-hal yang positif dari perbedaan yang ada.

Ketiga, dari segi model interaksi (model of cultural interaction), elit agama diharapkan dapat mengubah sikap isolatif dan menghindar (isolation and avoidance) menuju sikap integratif, interaktif yang menunjukkan penerimaan interaksi terhadap unsur-unsur lain yang berbeda (acceptance) bahkan masyarakat sendiri diharapkan mampu mentransformasi sendiri model interaksi yang saling menguntungkan antara pribumi dan salafi.

Keempat, dari segi pendekatan dalam ceramah atau pengajian (approach to teaching and management), dakwah agama/pengajian tidak hanya diarahkan bagaimana memahami kelompok sendiri tetapi juga belajar tentang dan dari orang lain (learning about other and from other). Sehingga nuansa monokultural diarahkan ke multikultural demi terwujudnya perbedaan yang tidak menghalangi kedamaian.

\section{Simpulan}

Keberadaan pribumi dan salafi sulit (untuk tidak mengatakan tidak mungkin) disatukan karena sudah melibatkan keyakinan akan cara pandang terhadap kebenaran. Perbedaan itu bukan untuk disatukan tetapi bagaimana perbedaan tersebut tidak menghalangi kedamaian. Kontestasi yang berujung konflik antara salafi dan pribumi di Lombok bisa diminimalisasi dengan menjadikan multicultural competence sebagai salah satu upaya manajemen konflik. Manajemen konflik yang dimaksud adalah konflik yang dikelola dan bukan dimusnahkan, karena memusnahkan konflik bukan hanya sulit atau mustahil, tetapi ditakutkan akan metamorfosa ke bentuk-bentuk yang lain. 
Unsur terpenting yang diinginkan oleh multicultural competence ini adalah adanya resiprokasi nilai dalam mewujudkan relasi damai seperti hormati yang lain jika ingin dihormati atau jangan mencubit jika tidak ingin dicubit. Islam sendiri mengajarkan, sayangi yang di bumi maka yang di langitpun akan menyayangi (irhamu' man fi al-ardhi, yarhamkum man fi al-sama').

Multicultural competence adalah kompetensi yang terdiri dari kesadaran akan perbedaan (awareness), pengetahuan tentang perbedaan (knowledge), kemampuan atau keterampilan (skill) serta sikap (attitude) dalam berinteraksi dan reaksi terhadap perbedaan. Multicultural competence bukan hanya persoalan pendidikan formal tetapi juga kehidupan real di tengah masyarakat. Elit agama yang berhadapan langsung dengan mayarakat (kelompok agama/aliran keagamaan) berperan penting dalam mewujudkan multicultural competence yang salah satu tujuannya adalah mengubah pola pikir dari my perspective is right and only one menuju my perspective is one of many sampai kepada my perspective is changing and being enhanced.

Kekurangan dari penelitian ini adalah karena lebih fokus pada pandangan pribumi desa dan kota terhadap salafi di desa dan di kota dan bukan sebaliknya. Karena itu, diperlukan kajian selanjutnya yang diharapkan bisa memberikan pandangan lebih jauh dengan menggunakan sudut pandang Salafi, baik desa dan kota terhadap pribumi desa maupun kota demi mewujudkan damai dalam perbedaan.

\section{Daftar Pustaka}

Abdurrachman. 2013. Media Bina Ilmiah. Volume 7, No. 6, Desember

Edward, Alexander Kyei. 2015. Otherness Development Model for Assessing Multicultural Competencies for Educational Leadership. Thomas Edison State College

Faizah. 2012a. Gerakan Salafi di Lombok, Tulisan dalam Harmon. Jurnal Multikultural EB Multireligius: Vol. 11 No. 4, Oktober - Desember

Faizah, 2012b, Pergulatan Teologi Salafi dalam Mainstream Keberagamaan Masyarakat Sasak. Ulumuna Jurnal Studi KeIslaman: Volume 16 Nomor 2 Desember

Hamid, Abdul \& Yaya. 2010. Pemikiran Modern dalam Islam. Bandung: Pustaka Setia

el Harakah Jurnal Budaya Islam Vol.18 No.1 Tahun 2016 
Lee, Heekap. 2015. Building a community of Salom, What The bible says about multicultural education. ICCTE Journal. Volume 10. No. 2, Agustus .

Misrawi, Zuhairi. 2013. Kesadaran Multikultural dan Deradikalisasi Pendidikan Islam: Pengalaman Bhinneka Tunggal Ika dan Qabul al-Akhar, Jurnal Pendidikan Islam : Volume II, Nomor 1, Juni

Nieto, S. (1994). Affirmation, solidarity, and critique: Moving beyond tolerance in multicultural education. Multicultural Education, 1(4), 9-12, 35-38.

Radar Lombok. 10 Juni 2015

Tantowi, Yusuf. 2009. Mengurai Konflik Sunnah Vs Bid'ah di Pulau Seribu Masjid, Kumpulan Tulisan dalam Agama dan Pergeseran Representasi, Konflik dan Integrasi di Indonesia. Jakarta: The Wahid Institute 